NASA/TM—2009-215509

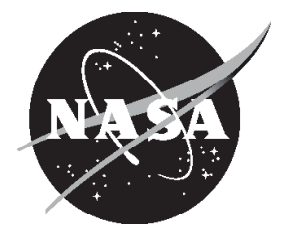

\title{
Young's Moduli of Cold and Vacuum Plasma Sprayed Metallic Coatings
}

S.V. Raj

Glenn Research Center, Cleveland, Ohio

R. Pawlik

The University of Toledo, Toledo, Ohio

W. Loewenthal

H.C. Starck, Inc., Cleveland, Ohio 


\section{NASA STI Program . . . in Profile}

Since its founding, NASA has been dedicated to the advancement of aeronautics and space science. The NASA Scientific and Technical Information (STI) program plays a key part in helping NASA maintain this important role.

The NASA STI Program operates under the auspices of the Agency Chief Information Officer. It collects, organizes, provides for archiving, and disseminates NASA's STI. The NASA STI program provides access to the NASA Aeronautics and Space Database and its public interface, the NASA Technical Reports Server, thus providing one of the largest collections of aeronautical and space science STI in the world. Results are published in both non-NASA channels and by NASA in the NASA STI Report Series, which includes the following report types:

- TECHNICAL PUBLICATION. Reports of completed research or a major significant phase of research that present the results of NASA programs and include extensive data or theoretical analysis. Includes compilations of significant scientific and technical data and information deemed to be of continuing reference value. NASA counterpart of peer-reviewed formal professional papers but has less stringent limitations on manuscript length and extent of graphic presentations.

- TECHNICAL MEMORANDUM. Scientific and technical findings that are preliminary or of specialized interest, e.g., quick release reports, working papers, and bibliographies that contain minimal annotation. Does not contain extensive analysis.

- CONTRACTOR REPORT. Scientific and technical findings by NASA-sponsored contractors and grantees.

- CONFERENCE PUBLICATION. Collected papers from scientific and technical conferences, symposia, seminars, or other meetings sponsored or cosponsored by NASA.

- SPECIAL PUBLICATION. Scientific, technical, or historical information from NASA programs, projects, and missions, often concerned with subjects having substantial public interest.

- TECHNICAL TRANSLATION. Englishlanguage translations of foreign scientific and technical material pertinent to NASA's mission.

Specialized services also include creating custom thesauri, building customized databases, organizing and publishing research results.

For more information about the NASA STI program, see the following:

- Access the NASA STI program home page at http://www.sti.nasa.gov

- E-mail your question via the Internet to help@ sti.nasa.gov

- Fax your question to the NASA STI Help Desk at 301-621-0134

- Telephone the NASA STI Help Desk at 301-621-0390

- Write to: NASA Center for AeroSpace Information (CASI) 7115 Standard Drive Hanover, MD 21076-1320 
NASA/TM—2009-215509

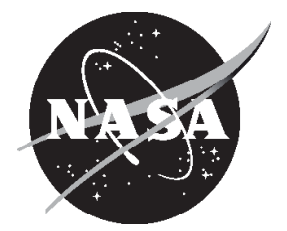

\section{Young's Moduli of Cold and Vacuum Plasma Sprayed Metallic Coatings}

S.V. Raj

Glenn Research Center, Cleveland, Ohio

R. Pawlik

The University of Toledo, Toledo, Ohio

W. Loewenthal

H.C. Starck, Inc., Cleveland, Ohio

National Aeronautics and

Space Administration

Glenn Research Center

Cleveland, Ohio 44135 
Trade names and trademarks are used in this report for identification only. Their usage does not constitute an official endorsement, either expressed or implied, by the National Aeronautics and Space Administration.

This work was sponsored by the Fundamental Aeronautics Program at the NASA Glenn Research Center.

Level of Review: This material has been technically reviewed by technical management.

Available from

NASA Center for Aerospace Information 7115 Standard Drive

Hanover, MD 21076-1320
National Technical Information Service 5285 Port Royal Road Springfield, VA 22161

Available electronically at http://gltrs.grc.nasa.gov 


\title{
Young's Moduli of Cold and Vacuum Plasma Sprayed Metallic Coatings
}

\author{
S.V. Raj \\ National Aeronautics and Space Administration \\ Glenn Research Center \\ Cleveland, Ohio 44135 \\ R. Pawlik \\ The University of Toledo \\ Toledo, Ohio 43606-3390 \\ W. Loewenthal \\ H.C. Starck, Inc. \\ Cleveland, Ohio 44117
}

\begin{abstract}
Monolithic metallic copper alloy and NiCrAlY coatings were fabricated by either the cold spray (CS) or the vacuum plasma spray (VPS) deposition processes. Dynamic elastic modulus property measurements were conducted on these monolithic coating specimens between $300 \mathrm{~K}$ and $1273 \mathrm{~K}$ using the impulse excitation technique. The Young's moduli decreased almost linearly with increasing temperature at all temperatures except in the case of the $\mathrm{CS} \mathrm{Cu}-23 \% \mathrm{Cr}-5 \% \mathrm{Al}$ and VPS NiCrAlY, where deviations from linearity were observed above a critical temperature. It was observed that the Young's moduli for VPS $\mathrm{Cu}-8 \% \mathrm{Cr}$ were larger than literature data compiled for $\mathrm{Cu}$. The addition of $1 \% \mathrm{Al}$ to $\mathrm{Cu}-$ $8 \% \mathrm{Cr}$ significantly increased its Young's modulus by 12 to $17 \%$ presumably due to a solid solution effect. Comparisons of the Young's moduli data between two different measurements on the same CS Cu$23 \% \mathrm{Cr}-5 \% \mathrm{Al}$ specimen revealed that the values measured in the first run were about $10 \%$ higher than those in the second run. It is suggested that this observation is due to annealing of the initial cold work microstructure resulting form the cold spray deposition process.
\end{abstract}

\subsection{Introduction}

Combustion liner materials in a liquid hydrogen $\left(\mathrm{LH}_{2}\right)$ fueled rocket engine experience extreme conditions due to a combination of environmental and thermo-mechanical effects, where the combustion flame temperatures in the chamber interior are about $3600 \mathrm{~K}$ whereas the backside of the $1 \mathrm{~mm}$ thick liner wall experiences cryogenic temperatures of $20 \mathrm{~K}[1,2,3,4,5,6]$. Copper and its alloys have been traditionally used as combustor liner materials in these regenerative rocket engines because of their high thermal conductivity to enable efficient heat transfer from the combustion flame to preheat the cryogenic $\mathrm{LH}_{2}$ flowing in the cooling channels. It is anticipated that the design of the next generation of reusable launch vehicles (RLVs) would use GRCop-84 (Cu-8(at.\%)Cr-4\%Nb) copper alloy liners due to its superior properties compared to other conventional copper alloys, such as NARloy-Z [7,8,9]. However, uncoated copper alloy liners undergo environmental degradation due to a combination of the spallation of the copper oxide scale and "blanching", which consists of repeated oxidation of the copper matrix and subsequent reduction of the oxide scale [6].

The application of protective coatings on GRCop-84 and other copper alloy substrates can either minimize or eliminate many of the problems experienced by uncoated liners and significantly extend their operational lives in RLVs. This factor potentially translates to increased component reliability, shorter depot maintenance turn around time and lower operational cost. In addition, the use of a suitable top coat to act as a thermal barrier can allow the engine to run at higher temperatures thereby resulting in its 
increased thermal efficiency. As a result, several types of ceramic $[1,5]$ and metallic $[10,11,12,13,14,15]$ coatings have been advocated as protective coatings for copper alloy liners. However, differences in the mechanical and thermophysical properties between the coatings and copper alloy substrates can lead to the development of large residual stresses and coating spallation as the coated liner experiences variations in temperature during processing and engine operation [16].

Recently, it was demonstrated that $\mathrm{CuCrAl}$ and NiCrAlY coatings deposited either by the cold spray (CS) or the vacuum plasma spray (VPS) techniques are potentially viable coatings for GRCop-84 combustion liners [14,15]. However, elastic moduli and thermophysical data for these sprayed coatings are either limited or nonexistent in the temperature range of interest for use in RLVs. Although some data on VPS alloys have been previously reported in the literature $[17,18,19]$, it is noted that these properties are sensitive to compositional and processing variables. Thus, it is essential that thermophysical data be generated on coatings sprayed under processing conditions and for compositions similar to those developed for spraying the GRCop-84 liners in order to ensure reliable design models to be developed.

The specific objectives of this paper are to report the temperature dependence of the dynamic, $E_{D}$, and static, $E_{S}$, Young's moduli of CS and VPS monolithic $\mathrm{Cu}-\mathrm{Cr}, \mathrm{CuCrAl}$, and NiCrAlY coating alloys between 300 and $1273 \mathrm{~K}$.

\subsection{Experimental Procedures}

\subsection{Alloy Composition and Processing}

Gas atomized copper alloy powders were procured from Crucible Research, Inc., Pittsburgh, Pennsylvania, whereas the NiAl and NiCrAlY powders were obtained from Homogenous Metals, Inc., New York, and Praxair, Indianapolis, Indiana, respectively. The nominal compositions of the alloy powders were $\mathrm{Cu}-8($ wt.\%)Cr, $\mathrm{Cu}-26($ wt.\%)Cr, Cu-8(wt.\%)Cr-1\%Al, Cu-23(wt.\%)Cr-5\%Al, and Ni17(wt.\%)Cr-6\%Al-0.5\%Y. Monolithic cylindrical coatings, typically $175-250 \mathrm{~mm}$ long and 19 to $25 \mathrm{~mm}$ thick, were fabricated by spraying the powders on rotating aluminum or steel mandrels by either CS or VPS. The $\mathrm{Cu}-23 \% \mathrm{Cr}-5 \% \mathrm{Al}$ coatings were cold sprayed at ASB Industries, Inc., Barberton, Ohio [20]. The $\mathrm{Cu}-8 \% \mathrm{Cr}, \mathrm{Cu}-26 \% \mathrm{Cr}, \mathrm{Cu}-8 \% \mathrm{Cr}-1 \% \mathrm{Al}$, and NiCrAlY coatings were deposited by the vacuum plasma spray method at Plasma Processes, Inc., Huntsville, Alabama. The coated mandrels were hot isostatically pressed (HIP) between 1073 and $1273 \mathrm{~K}$ under argon gas pressures varying between 100 and $210 \mathrm{MPa}$ for times varying between 1 and $4 \mathrm{hr}$.

Specimens were machined from the sprayed cylinders by electrodischarge machining (EDM). Dynamic Young's moduli measurements were made on specimens with dimensions $50 \times 4 \times 3 \mathrm{~mm}$ by the impulse excitation technique (IET) $[21,22,23]$ using a commercially available GrindoSonic MK5I test equipment equipped with a furnace and an environmental test chamber. The theoretical foundations of this technique for measuring elastic constants are described elsewhere [21,24,25]. The measurements were conducted between room temperature and $1273 \mathrm{~K}$ under flowing Ar. The bar specimen was supported at two points corresponding to its vibrational nodes, which occur at distances of $0.224 \mathrm{~L}$, where $L$ is the specimen length, from each end of the specimen. A small ceramic projectile propelled by low pressure Ar was used to lightly apply a mechanical impulse load on the specimen, and the generated outof-plane fundamental resonant frequency, $f_{R}$, of the bar in flexure at absolute temperature, $T$, was recorded by an acoustic microphone at the desired rate. The specimen temperature was increased at $100 \mathrm{~K} / \mathrm{hr}$, and the resonant frequency, time and temperature were automatically recorded every $5 \mathrm{~K}$ by a computerized data acquisition system. The uncorrected Young' modulus was determined from the equation [21,22,24]

$$
E_{D}=\left[0.9465^{*}\left\{M^{*}\left(f_{R}\right)^{2} / w\right\}\right](t / L)^{3} T_{1}
$$

where $M$ is the mass of the specimen in gm, and $w$ and $t$ are the width and thickness, respectively, of the specimen in $\mathrm{mm}$, and $T_{1}$ is a correction factor related to the Poisson's ratio, $v$, through 


$$
\begin{gathered}
T_{1}=1+ \\
-\left[\frac{8.585\left(1+0.0752 v+0.8109 v^{2}\right)\left(\frac{t}{L}\right)^{2}-0.868\left(\frac{t}{L}\right)^{4}}{1+6.338\left(1+0.1408 v+1.536 v^{2}\right)\left(\frac{t}{L}\right)^{2}}\right]
\end{gathered}
$$

A value of $v=0.33$ was assumed in evaluating $T_{1}$. It has been recommended that the values of $E_{D}$ be corrected for effects due to thermal expansion using [22]

$$
E_{D T}=E_{D 0}\left(\frac{f_{R}}{f_{0}}\right)\left[\frac{1}{\left(1+\alpha_{T} \Delta T\right)}\right]
$$

where $E_{D T}$ and $E_{D 0}$ are the Young's moduli are at test temperature and room temperature, respectively, $f_{0}$ is the resonant frequencies at room temperature, respectively, $\alpha_{T}$ is the average coefficient of thermal expansion (CTE) and $\Delta T$ is the temperature differential between test temperature and room temperature. The values of $\alpha_{T}$ in eq. (3) represent the average linear thermal expansion between room temperature and test temperature. Based on experimental measurements of $\alpha_{T}$ [26], applying the temperature correction given be eq. (3) to the experimental data resulted in a maximum decrease in the magnitude of $E_{D}$ by about 1.5 to $2.0 \%$ at the highest test temperature, which is insignificant in most applications. Thus, the values of $E_{D}$ reported in this paper do not include corrections for CTE.

Dynamic and static Young's moduli measurements were conducted on sprayed monolithic coating alloys. The static moduli were determined on round tensile NiCrAlY specimens with a gage length of $25 \mathrm{~mm}$ and gage diameter of $6.3 \mathrm{~mm}$ using point contact extensometers under engineering strain rates varying between $10^{-6}$ to $10^{-4} \mathrm{~s}^{-1}$. Since the magnitudes of $E_{S}$ were independent of strain rate, the strain rates at which static moduli data were generated are not distinguished in this paper. These tests were conducted either in air in the case of NiCrAlY or under flowing Ar in the case of the copper alloys between room temperature and $1273 \mathrm{~K}$. There was insufficient material of the near full density $\mathrm{Cu}-26 \% \mathrm{Cr}$ (V2-03-524) batch to produce specimens of sufficient length for dynamic Young's modulus measurements.

\subsection{Results and Discussion}

\subsection{Density Measurements}

Table 1 gives the bulk density, $\rho_{\text {experimental }}$, for the different coatings ${ }^{1}$ measured at room temperature. Microstructural observations of $\mathrm{Cu}-26 \mathrm{Cr}$ (V2-02-27B) revealed that it had a relatively higher amount of porosity compared to the other sprayed coatings, which were nearly $100 \%$ dense. The porosity content of this batch was determined to be about $35 \%$ from a comparison of the bulk and immersion densities, where

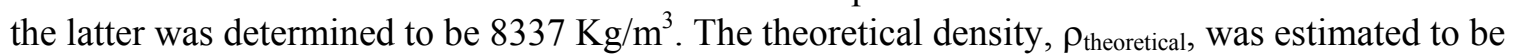
$8410 \mathrm{Kg} / \mathrm{m}^{3}$. This high level of porosity was attributed to non-optimized processing conditions for this alloy. Although the density of NiCrAlY (V2-02-27E) is similar to the experimental values of 6900 to $7500 \mathrm{Kg} / \mathrm{m}^{3}[18,27]$ and theoretical value of $7000 \mathrm{Kg} / \mathrm{m}^{3}$ reported for plasma sprayed NiCrAlY [27], this batch had a larger amount of porosity than NiCrAlY (V2-03-528), which was 100\% dense. The porosity

\footnotetext{
${ }^{1}$ The bulk density measurements were conducted at the Thermophysical Properties Research Laboratory, Inc. (TPRL), West Lafayette, Indiana.
} 
content of the NiCrAlY batch V2-02-27E was estimated to be about 7\% based on a comparison of its density with that of the NiCrAlY batch, V2-03-528.

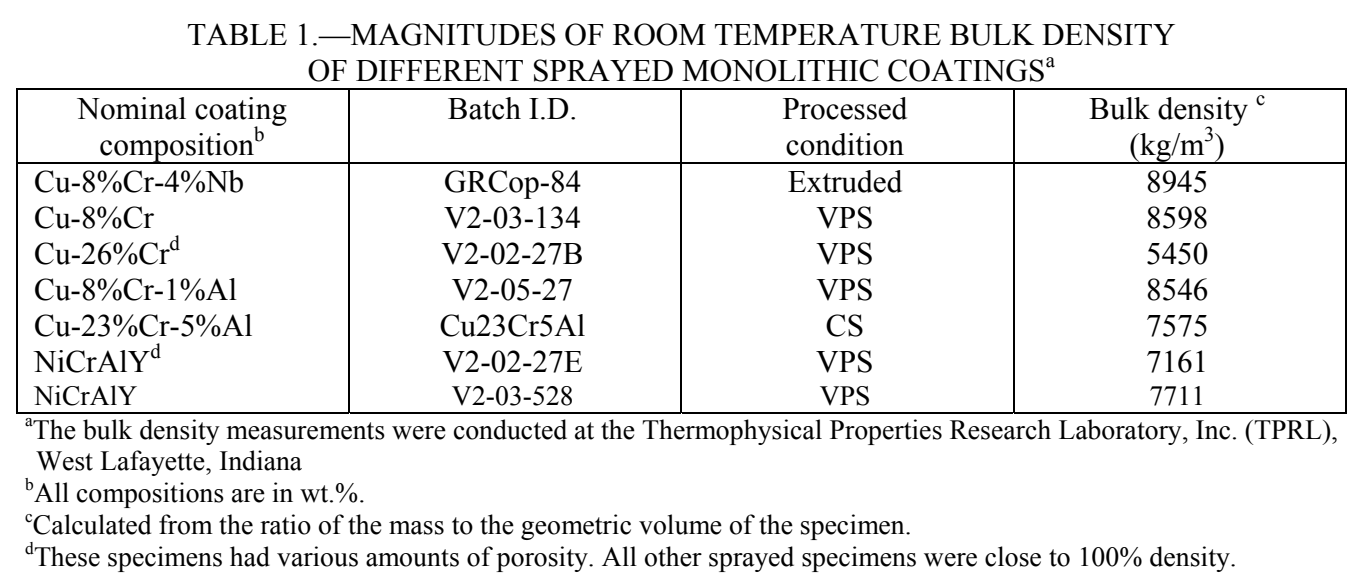

\subsection{Vacuum Plasma Sprayed Coatings}

\subsubsection{Cu-Cr Coatings}

Figure 1 shows the decrease in $E_{D}$ with increasing $\mathrm{T}$ for the $\mathrm{Cu}-8 \mathrm{Cr}$ and $\mathrm{Cu}-26 \mathrm{Cr}$ monolithic coatings. Owing to the limited solid solubility of $\mathrm{Cr}$ in $\mathrm{Cu}$ [28], the $\mathrm{Cu}-\mathrm{Cr}$ alloy can be considered to be a mechanical mixture. Fig. 1 also shows the predicted values, $E_{\mathrm{ROM}}$, calculated from the rule of mixtures (ROM) model:

$$
E_{\mathrm{ROM}}=V_{\mathrm{Cr}} E_{\mathrm{Cr}}+\left(1-V_{\mathrm{Cr}}\right) E_{\mathrm{Cu}}
$$

where $V_{\mathrm{Cr}}$ is the volume fraction of the Cr phase, and $E_{\mathrm{Cr}}$ and $E_{\mathrm{Cu}}$ are the Young's moduli of pure $\mathrm{Cr}$ and $\mathrm{Cu}$, respectively. The temperature dependence of $E_{\mathrm{Cr}}$ and $E_{\mathrm{Cu}}$ were calculated from the equations published by Frost and Ashby [29] and Raj and Langdon [30] for the Young's moduli of $\mathrm{Cr}$ and $\mathrm{Cu}$, respectively. The density-corrected data for $\mathrm{Cu}-26 \mathrm{Cr}$ are also shown, where the experimental values were corrected by multiplying them by ( $\left.\rho_{\text {theoretical }} / \rho_{\text {experimental }}\right)$.

The Young's moduli for the two alloys decrease almost linearly with increasing temperature similar to other materials [29,31]. The density-corrected and uncorrected experimental data could be well represented by the equation [32]

$$
E_{D}=\mathrm{E}_{0}-\left(\partial E_{D} / \partial T\right) T
$$

where $E_{0}$ is the extrapolated Young's modulus to absolute zero ${ }^{2}$ and $\left(\partial E_{D} / \partial T\right)$ is the rate of change of Young's modulus with absolute temperature. The magnitudes of $E_{0}$ and $\left(\partial E_{D} / \partial T\right)$ determined from linear regression analyses of the experimental data between 300 and $750 \mathrm{~K}$ are given in Table 2 , where $R_{d}^{2}$ is the coefficient of determination. Above $750 \mathrm{~K}$, the data deviated from the regressed lines to lower values presumably due to the effects of significant atomic diffusion. The presence of $\mathrm{Cr}$ particles in $\mathrm{Cu}-8 \% \mathrm{Cr}$ increases the magnitude of $E_{D}$ above that for $\mathrm{Cu}$ [30] by about $12 \%$ at room temperature but their effect decreases with increasing temperature so that the $E_{D}$ for both materials are comparable above $900 \mathrm{~K}$.

\footnotetext{
${ }^{2} \mathrm{It}$ is important to note that the magnitude of $E_{0}$ is likely to be higher than the actual value of $E_{D}$ at $0 \mathrm{~K}$ [31].
} 


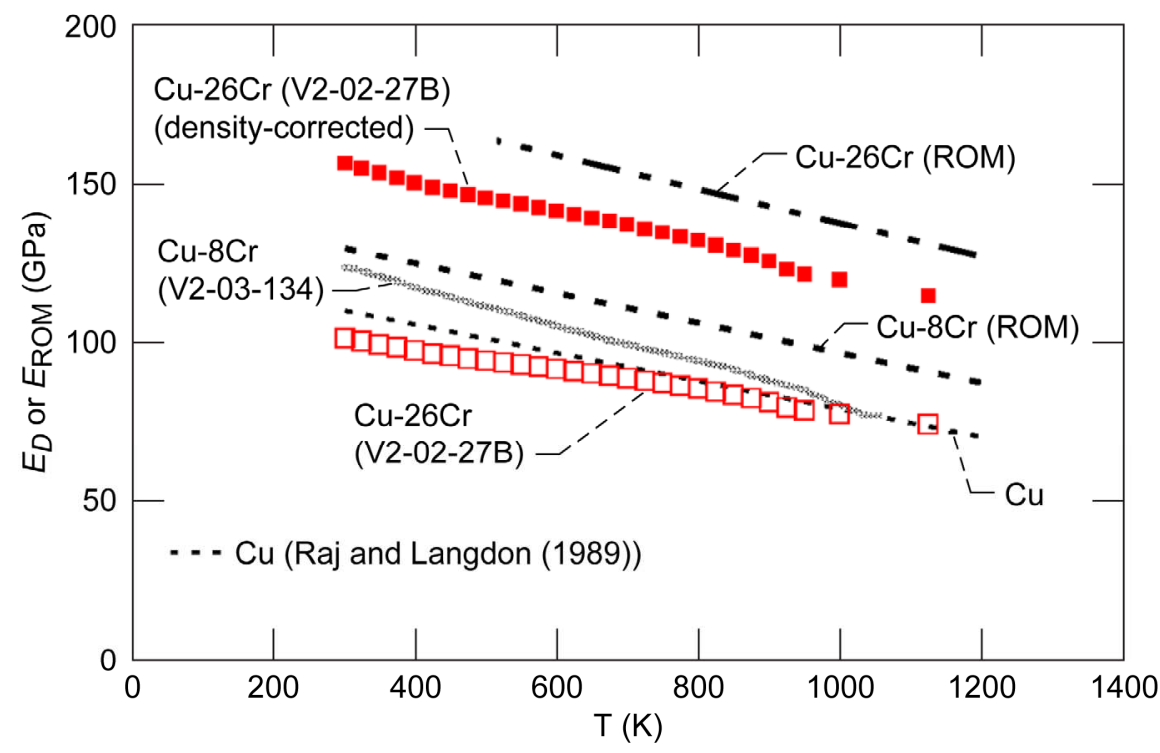

Figure 1.-Comparison of the experimental dynamic Young's moduli for VPS $\mathrm{Cu}-8 \% \mathrm{Cr}$ and $\mathrm{Cu}-26 \% \mathrm{Cr}$ with compiled data for $\mathrm{Cu}$ [30] and predicted values determined by the rule of mixtures.

TABLE 2.-REGRESSION PARAMETERS DESCRIBING THE TEMPERATURE DEPENDENCE OF THE YOUNG'S MODULI FOR MONOLITHIC COATINGS

\begin{tabular}{|c|c|c|c|c|c|}
\hline $\begin{array}{l}\text { Nominal coating } \\
\text { composition }^{\mathrm{a}}\end{array}$ & Batch I.D. & $\begin{array}{l}\text { Processed } \\
\text { condition }\end{array}$ & $\begin{array}{c}E_{0} \\
(\mathrm{GPa})\end{array}$ & $\begin{array}{c}\partial E_{D} / \partial T \\
(\mathrm{GPa} / \mathrm{K}) \\
\end{array}$ & $R_{d}^{\mathrm{b}}$ \\
\hline $\mathrm{Cu}-8 \% \mathrm{Cr}$ & V2-03-134 & VPS & 142.0 & 0.060 & 0.997 \\
\hline $\mathrm{Cu}-26 \% \mathrm{Cr}^{\mathrm{b}}$ & V2-02-27B & VPS & 110.0 & 0.030 & 0.995 \\
\hline $\mathrm{Cu}-26 \% \mathrm{Cr}^{\mathrm{c}}$ & V2-02-27B & VPS & 169.8 & 0.047 & 0.998 \\
\hline $\mathrm{Cu}-8 \% \mathrm{Cr}-1 \% \mathrm{Al}$ & V2-05-27 & VPS & 158.7 & 0.065 & 0.988 \\
\hline $\mathrm{Cu}-23 \% \mathrm{Cr}-5 \% \mathrm{Al}$ & $\begin{array}{c}\mathrm{Cu} 23 \mathrm{Cr} 5 \mathrm{Al} \\
\text { (specimen } 3 \text { ) }\end{array}$ & $\begin{array}{c}\text { CS } \\
\text { (Run 1) }\end{array}$ & 166.0 & 0.071 & 0.989 \\
\hline $\mathrm{Cu}-23 \% \mathrm{Cr}-5 \% \mathrm{Al}$ & $\begin{array}{l}\mathrm{Cu} 23 \mathrm{Cr} 5 \mathrm{Al} \\
\text { (specimen } 3 \text { ) }\end{array}$ & $\begin{array}{c}\text { CS } \\
\text { (Run 2) }\end{array}$ & 147.3 & 0.059 & 0.995 \\
\hline $\mathrm{NiCrAlY}^{\mathrm{b}}$ & V2-02-27E & VPS & 221.8 & 0.057 & 0.999 \\
\hline NiCrAlY & V2-03-528 & VPS & 232.7 & 0.060 & 0.998 \\
\hline
\end{tabular}

${ }^{\mathrm{a} A l l}$ compositions are in wt.\%.

${ }^{\mathrm{b}}$ These specimens had various amounts of porosity. All other sprayed specimens were close to $100 \%$ density.

${ }^{\mathrm{c}}$ Density-corrected equation.

The uncorrected values of $E_{D}$ for $\mathrm{Cu}-26 \% \mathrm{Cr}$ are similar to the mean regression data for pure $\mathrm{Cu}$ [30] and lie below the experimental data for $\mathrm{Cu}-8 \% \mathrm{Cr}$ due to the fact that this batch had a considerable amount of porosity. However, the density-corrected values for $\mathrm{Cu}-26 \% \mathrm{Cr}$ with a calculated value of $V_{\mathrm{Cr}}$ of about 30 vol.\% $\mathrm{Cr}$ are higher than those for $\mathrm{Cu}-8 \% \mathrm{Cr}$ for which the calculated $V_{\mathrm{Cr}} \sim 9$ vol.\%. An examination of Fig. 1 shows that the values of $E_{D}$ predicted by the rule of mixtures are significantly higher than the experimental data especially for $\mathrm{Cu}-26 \% \mathrm{Cr}$.

\subsubsection{Effect of Al addition}

Figure 2 compares the temperature dependence of $E_{D}$ for $\mathrm{Cu}-8 \% \mathrm{Cr}-1 \% \mathrm{Al}$ with those for $\mathrm{Cu}[30]$ and $\mathrm{Cu}-8 \% \mathrm{Cr}$. The data for $\mathrm{Cu}-8 \% \mathrm{Cr}-1 \% \mathrm{Al}$ shown in Fig. 2 represent the average values of measurements made on two specimens. It is noted that these two sets of data almost overlapped each other between 300 and $1000 \mathrm{~K}$ thereby indicating excellent reproducibility in the measurements. The magnitudes of $E_{D}$ for the alloys exhibit an inverse linear dependence on absolute temperature, where the values of $E_{0}$ and 


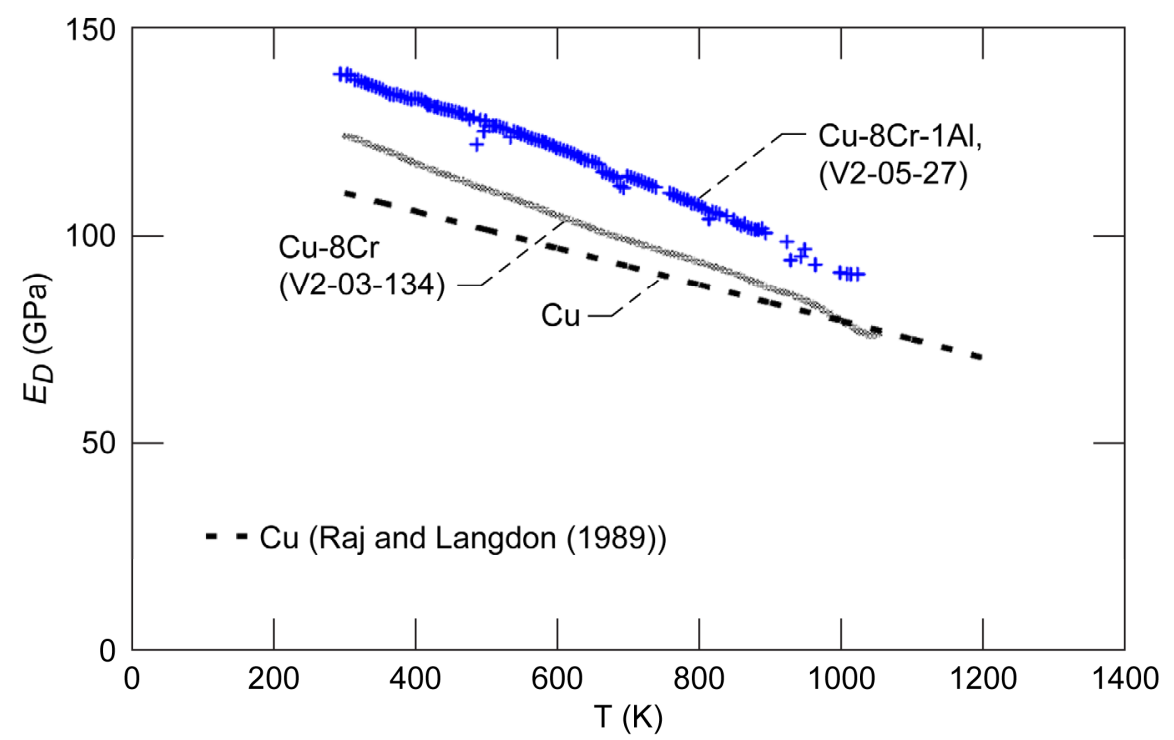

Figure 2.-Comparison of the experimental dynamic Young's moduli for VPS Cu-8\%Cr-1\%Al and $\mathrm{Cu}-8 \% \mathrm{Cr}$ with compiled data for $\mathrm{Cu}[30]$.

$\left(\partial E_{D} / \partial T\right)$ are given in Table 1. It is clear from Fig. 2 that the addition of $1 \% \mathrm{Al}$ to $\mathrm{Cu}-8 \% \mathrm{Cr}$ results in a significant increase in the elastic modulus by 12 to $17 \%$ between 300 and $1000 \mathrm{~K}$ through its influence on $E_{0}$; its effect on $\left(\partial E_{D} / \partial T\right)$ is relatively insignificant (Table 2). Since Al exists in solid solution in $\mathrm{Cu}$ at this relatively low compositional level, this increase in $E_{D}$ can be attributed entirely due to a solid solution effect. Noting that the densities of $\mathrm{Cu}-8 \% \mathrm{Cr}$ and $\mathrm{Cu} 8 \% \mathrm{Cr}-1 \% \mathrm{Al}$ are similar (Table 1), an examination of eq. (1) suggests that the lattice distortion due to the presence of $\mathrm{Al}$ atoms in the $\mathrm{Cu}$ lattice most likely increased the magnitude of $f_{R}$ over the base alloy.

\subsubsection{NiCrAlY Coatings}

Figure 3 compares the magnitudes of dynamic and static Young's moduli for the two batches of NiCrAlY coatings. The data of Cook et al. $[19,33]$ for an alloy of similar composition are also shown in the figure for comparison. The data are well represented by eq. (5) between 300 and $1000 \mathrm{~K}$. The two sets of data for batch V2-03-528, which are nearly identical, lie above the data for batch V2-02-27E consistent with their higher density (Table 1). The differences in the magnitudes of Young's moduli determined for batches V2-02-27E and V2-03-528 varied between 2.5 and 7.5\% in the temperature range 300 to $1150 \mathrm{~K}$ primarily reflected in the magnitudes of $E_{0}$ rather than $\left(\partial E_{D} / \partial T\right)$. The values reported by Cook et al. $[19,33]$ are in excellent agreement with the magnitudes of $E_{D}$ determined for batch V2-02-27E. The static moduli values are lower than the dynamic moduli and exhibit more scatter especially at the higher temperatures.

\subsection{Cold sprayed coatings}

The magnitudes of $E_{D}$ decreased linearly with increasing absolute temperature for cold sprayed Cu$23 \mathrm{Cr}-5 \mathrm{Al}$ alloys between 300 and $700 \mathrm{~K}$ (Fig. 4). The data for VPS Cu-8Cr-1 Al are shown for comparison. Deviation from linearity was observed above $700 \mathrm{~K}$. Interestingly, the Young's moduli were higher for specimens tested in the first run, "Run 1", compared to measurements made in the second run, "Run 2". As shown in Fig. 4, these differences were quite reproducible in repeat tests. Noting that the cold spray process involves extensive deformation of the powder particles during the deposition process [34], the higher values of $E_{D}$ observed in "Run 1" can be attributed to a highly cold worked state of the coating. Thus, the decrease in the magnitudes of $E_{D}$ in Run 2 can be attributed to the effects of annealing 


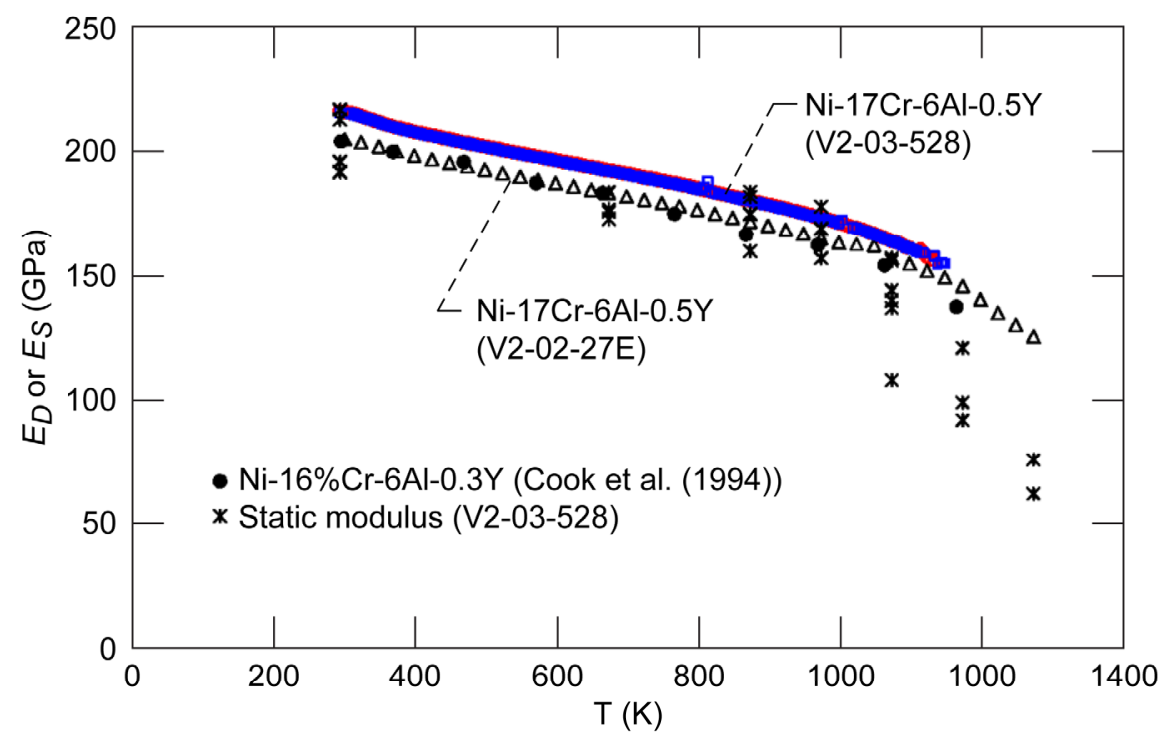

Figure 3.-Comparison of the experimental dynamic and static Young's moduli data for two batches of VPS Ni-17\% Cr-6\%Al-0.5\%Y coating. Data determined from two measurements for NiCr AIY (V2-03-528) are shown. Literature data on $\mathrm{Ni}-16 \% \mathrm{Cr}-6 \mathrm{Al}-0.3 \mathrm{Y}$ are shown foe comparison [19, 33].

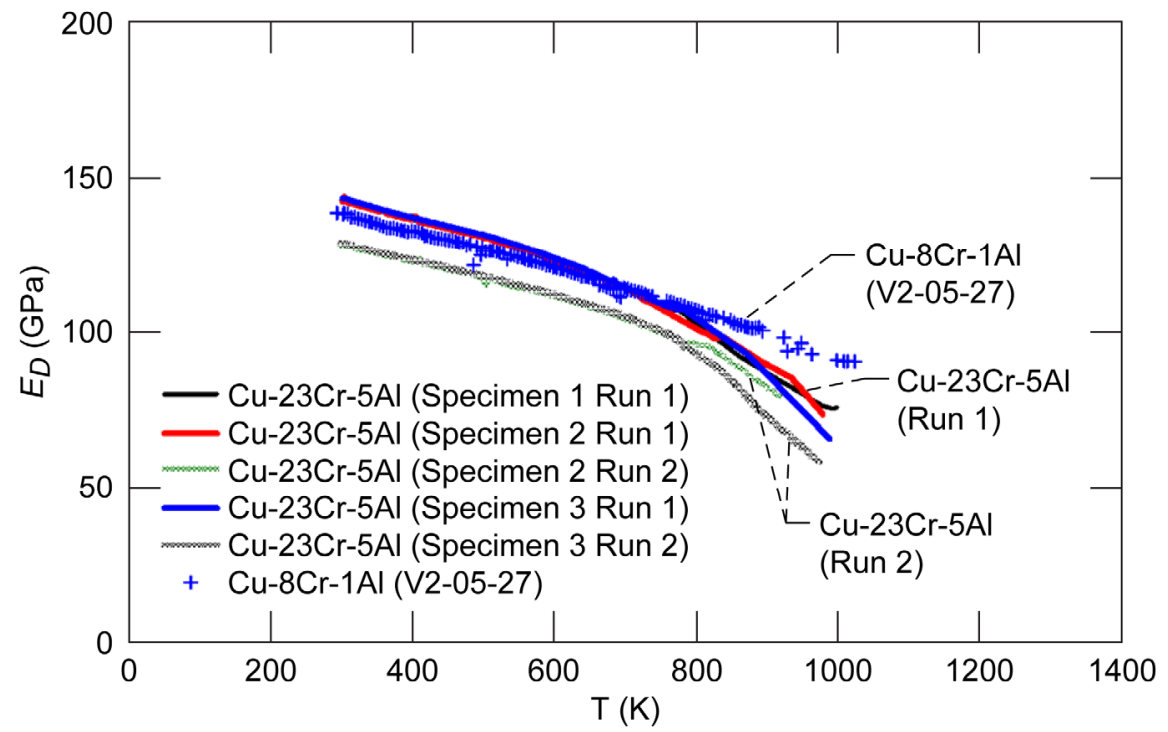

Figure 4.-Comparison of the experimental dynamic Young's moduli data for CS Cu-23\%Cr-5\%Al with that for VPS Cu- $8 \% \mathrm{Cr}-1 \% \mathrm{Al}$ coatings. The first set of measurements conducted on a $\mathrm{Cu}-23 \% \mathrm{Cr}-5 \% \mathrm{Al}$ specimen corresponding to the as-received material is termed "Run 1" while the repeat set of measurements are termed "Run 2". Three sets of data are shown for Run 1 and two sets are shown for Run 2. 
as the specimens were heated from room temperature to about $1000 \mathrm{~K}$ in Run 1. Although the Young's moduli for $\mathrm{Cu}-23 \mathrm{Cr}-5 \mathrm{Al}$ are comparable to those for $\mathrm{Cu}-8 \mathrm{Cr}-1 \mathrm{Al}$ below $700 \mathrm{~K}$ in measurements made in Run 1, they exhibit a relatively steep drop with increasing temperature above $700 \mathrm{~K}$ dropping to values well below those for $\mathrm{Cu}-8 \mathrm{Cr}-1 \mathrm{Al}$. Significantly, increasing the amount of $\mathrm{Al}$ from 1 to $5 \%$ and the $\mathrm{Cr}$ from 8 to $23 \%$ has a negligible effect on the magnitudes of $E_{D}$ for these two alloys below $700 \mathrm{~K}$.

The precise reason as to why $E_{D}$ for $\mathrm{Cu}-23 \mathrm{Cr}-5 \mathrm{Al}$ decreases below that for $\mathrm{Cu}-8 \mathrm{Cr}-1 \mathrm{Al}$ above this temperature is still unclear but two possible causes could be considered. First, the increasing dissolution of the $\alpha$-Cr precipitates with increasing temperature may have caused the observed decrease in $E_{D}$. However, since the maximum solid solubility of $\mathrm{Cr}$ in $\mathrm{Cu}$ is only about 0.89 (at.\%) [28], it does not appear probable that $\mathrm{Cr}$ dissolution can account for the present observations especially since VPS Cu-8Cr-1Al does not show a similar significant decrease in $E_{D}$ with increasing temperature. Second, extensive secondary recrystallization of the $(\mathrm{Cu}, \mathrm{Al})$ matrix resulting from the prior deformation of the powder particles and the presence of the $\alpha-\mathrm{Cr}$ phase may have resulted in strong annealed texture in the specimens. Since it is well known that elastic moduli are sensitive to texture, this explanation appears to be the most plausible in the present instance.

\subsection{Summary and Conclusions}

The temperature dependence of the dynamic Young's moduli of several copper alloy and NiCrAlY monolithic coating alloys fabricated either by the cold spray or vacuum plasma spray process were measured by the impulse excitation techniques between 300 and $1000 \mathrm{~K}$. Tensile static moduli measurements were also conducted on the NiCrAlY coating in the same temperature range. The Young's moduli decrease with increasing temperature, where this decrease is linear at low and intermediate temperatures. The Young's moduli for $\mathrm{Cu}-8 \% \mathrm{Cr}$ were higher than compiled data for pure $\mathrm{Cu}$ [30] below $1000 \mathrm{~K}$ but below the values predicted by the rule of mixtures. The experimental values of $\mathrm{Cu}-26 \% \mathrm{Cr}$ coating exhibited values similar to the compiled literature values presumably due to a large amount of porosity. However, the density-corrected data were significantly higher than the values for pure $\mathrm{Cu}$ and $\mathrm{Cu}-8 \% \mathrm{Cr}$. The addition of $1 \% \mathrm{Al}$ to $\mathrm{Cu}-8 \% \mathrm{Cr}$ significantly increased the dynamic Young's modulus of the alloy presumably due to a solid solution effect. There was no significant difference in the Young's moduli data for the as-received cold sprayed $\mathrm{Cu}-23 \% \mathrm{Cr}-5 \% \mathrm{Al}$ and vacuum plasma sprayed $\mathrm{Cu}-8 \% \mathrm{Cr}-$ $1 \% \mathrm{Al}$ coatings below $700 \mathrm{~K}$ thereby suggesting that the variations in the $\mathrm{Al}$ and $\mathrm{Cr}$ content between the two alloys did not affect $E_{D}$. However, the magnitudes of $E_{D}$ for the cold sprayed $\mathrm{Cu}-23 \% \mathrm{Cr}-5 \% \mathrm{Al}$ determined in the second run of measurements were lower than the values obtained on the as-received material in the first run presumably due to the effects of annealing on the as-received cold worked microstructure of the alloy. The dynamic Young's moduli for the NiCrAlY coating were reproducible and larger than the static moduli for the coating.

\section{References}

1. R J. Quentmeyer, "Experimental Fatigue Life Investigation of Cylindrical Thrust Chambers," NASA TM X-73665, Lewis Research Center, OH (1977).

2. D.K. Huzel and D.H. Huang, "Modern Engineering for Design of Liquid-Propellant Rocket Engines," Progress in Astronautics and Aeronautics, vol. 147, A.R. Seebass, ed., American Institute of Aeronautics and Astronautics, Inc., Washington, DC, pp. 67-134 (1992).

3. J. Singh, G. Jerman, B. Bhat and R. Poorman, "Microstructural Stability of Wrought, Laser and Electron Beam Glazed NARloy-Z Alloy at Elevated Temperatures," NASA TM-108431, NASA Marshall Space Flight Center, Huntsville, AL, (1993).

4. H.J. Kasper, "Thrust Chamber Life Prediction," Advanced High Pressure $\mathrm{O}_{2} / \mathrm{H}_{2}$ Technology, NASA CP-2372, S.F. Morea and S.T. Wu, eds., NASA Marshall Space Flight Center, Huntsville, AL, pp. 36-43 (1985). 
5. R.J. Quentmeyer, "Rocket Thrust Chamber Thermal Barrier Coatings," Advanced High Pressure $\mathrm{O}_{2} / \mathrm{H}_{2}$ Technology, NASA CP-2372, S.F. Morea and S.T. Wu, eds., NASA Marshall Space Flight Center, Huntsville, AL, pp. 49-58 (1985).

6. D.B. Morgan and A.C. Kobayashi, " Main Combustion Chamber and Cooling Technology StudyFinal Report," NASA CR-184345, NASA Marshall Space Flight Center, Huntsville, AL (1989).

7. D. Ellis and D. Keller, NASA/CR - 2000-210055, NASA Glenn Research Center, Cleveland, OH (2000).

8. R. Holmes, D. Ellis and T. McKechnie, "Robust Low Cost Aerospike/RLV Combustion Chamber by Advanced Vacuum Plasma Process," Countdown to the Millennium Proceedings, $36^{\text {th }}$ Space Congress, Canaveral Council of Technical Societies, Cape Canaveral, FL (1999).

9. R. Hickman, T. McKechnie and R. Holmes, "Material Properties of Vacuum Plasma Sprayed Cu$8 \mathrm{Cr}-4 \mathrm{Nb}$ for Liquid Rocket Engines," Paper No. AIAA 2001-3693, $37^{\text {th }}$ AIAA/ASME/SAE/ ASEE/Joint Propulsion Conference, Salt Lake City, UT, American Institute of Aeronautics and Astronautics, Inc., pp. 1-9 (2001).

10. K.T. Chiang, P.D. Krotz and J.L. Yuen, Surf. Coat. Technol. 76, pp. 14-19 (1995).

11. K.T. Chiang and J.P. Ampaya, Surf. Coat. Technol. 78, pp. 243-247 (1996).

12. T.A. Wallace, R.K Clark and K.T. Chiang, J. Spacecraft Rockets 35, pp. 546-51 (1998).

13. S. Elam, R. Holmes, T. McKechnie, R. Hickman and T. Pickens, "VPS GRCop-84 Chamber Liner Development Efforts," $52^{\text {nd }}$ JANAF Propulsion Meeting/ $1^{\text {st }}$ Liquid Propulsion Subcommittee Meeting, Las Vegas, Chemical Propulsion Information Agency, The Johns Hopkins University, Baltimore, MD, pp. 1-10 (2004).

14. S.V. Raj, L.J. Ghosn, C. Robinson and D. Humphrey, Mater. Sci. Eng. A. 457, pp. 300-312 (2007).

15. S.V. Raj, C. Barrett, J. Karthikeyan and R. Garlick, Surf. \& Coat. Tech. 201, pp. 7222-7234 (2007).

16. L.J. Ghosn and S.V. Raj, Ceramic Engineering Science Proceedings 23, pp. 409-416 (2002).

17. P.A. Siemers and R.L. Mehan, "Mechanical and Physical Properties of Plasma Sprayed Stabilized Zirconia," Report No. 83CRD149, General Electric Company, Schenectady, NY (1983).

18. R. Brandt, L. Pawlowski, G. Neuer, and P. Fauchais, High Temp. High Press. 18, pp. 65-77 (1986).

19. W.J. Brindley, J. Thermal Spray Technology 6, pp. 85-90 (1997).

20. J. Karthikeyan, "Development of Oxidation Resistant Coatings on GRCop-84 Substrates by Cold Spray Process," NASA/CR - 2007-214706, NASA Glenn Research Center, Cleveland, OH (2007).

21. S. Spinner and W.E. Tefft, Proc. Amer. Soc. Testing Mater. 61, pp. 1221-1238 (1961).

22. ASTM Standard E 1876-01 "Standard Test Method for Dynamic Young's Modulus, Shear Modulus, and Poisson's Ratio by Impulse Excitation of Vibration," sec. 3, vol. 03.01, ASTM International, West Conshohocken, PA. pp. 1122-1137 (2004)

23. R. Schmidt, V. Wicher and R. Tilgner, Polymer Testing 24, pp. 197-203 (2005).

24. G. Pickett, Proc. Amer. Soc. Testing Mater. 45, pp. 846-865 (1945).

25. Elastic Constants and their Measurements, E. Schreiber, O.L. Anderson and N. Soga, McGraw-Hill, New York, NY (1973).

26. S.V. Raj and A. Palczer, unpublished research, Glenn Research Center, Cleveland, OH (2006).

27. J.H. Shin, S.K. Hur, C.G. Ha, Y.G. Jung and U. Paik, J. Alloys Compounds 313, 248-257 (2000).

28. Binary Alloy Phase Diagrams, T.B. Massalski, H. Okamoto and P.R. Subramanian, eds., ASM International, Materials Park, Cleveland, OH (1990).

29. H.J. Frost and M.F. Ashby, Deformation-Mechanism Maps: The Plasticity and Creep of Metals and Ceramics, Pergamon Press, Oxford, U.K. (1982).

30. S.V.Raj and T.G. Langdon, Acta Met. 37, 843-852 (1989).

31. C. Kittel, Introduction to Solid State Physics, $\left(4^{\text {th }}\right.$ ed.), Wiley Eastern, New Delhi, India (1974).

32. T.G. Langdon, Metals Forum 1, pp. 59-70 (1978).

33. L.S. Cook, A. Wolfenden and W.J. Brindley, J. Mater. Sci. 29, pp. 5104-5108 (1994).

34. T.Schmidt, F. Gärtner, H. Assadi and H. Kreye, Acta Mater. 54, pp. 729-742 (2006). 


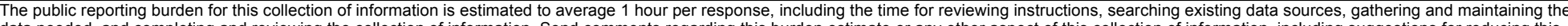

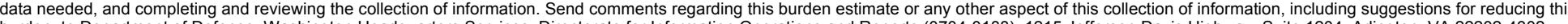

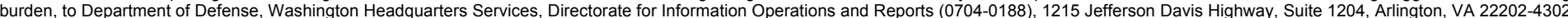

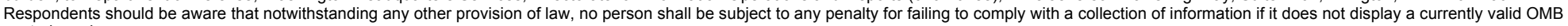
control number.

control number.
PLEASE DO NOT RETURN YOUR FORM TO THE ABOVE ADDRESS

\section{REPORT DATE $(D D-M M-Y Y Y Y)$ \\ 2. REPORT TYPE \\ 3. DATES COVERED (From - To)}

01-03-2009

\section{TITLE AND SUBTITLE}

Technical Memorandum

Young's Moduli of Cold and Vacuum Plasma Sprayed Metallic Coatings

\section{5a. CONTRACT NUMBER}

5b. GRANT NUMBER

5c. PROGRAM ELEMENT NUMBER

6. AUTHOR(S)

Raj, S., V.; Pawlik, R.; Loewenthal, W.

\section{5d. PROJECT NUMBER}

5e. TASK NUMBER

5f. WORK UNIT NUMBER

WBS 561581.02.08.03.15.02

8. PERFORMING ORGANIZATION

REPORT NUMBER

E-16678

National Aeronautics and Space Administration

John H. Glenn Research Center at Lewis Field

Cleveland, Ohio 44135-3191

\section{SPONSORING/MONITORING AGENCY NAME(S) AND ADDRESS(ES)}

National Aeronautics and Space Administration

Washington, DC 20546-0001

\section{SPONSORING/MONITORS ACRONYM(S) \\ NASA \\ 11. SPONSORING/MONITORING REPORT NUMBER \\ NASA/TM-2009-215509}

\section{DISTRIBUTION/AVAILABILITY STATEMENT}

Unclassified-Unlimited

Subject Categories: 15, 16, 23, 26 and 31

Available electronically at http://gltrs.grc.nasa.gov

This publication is available from the NASA Center for AeroSpace Information, 301-621-0390

\section{SUPPLEMENTARY NOTES}

Submitted to Materials Science and Engineering A.

\section{ABSTRACT}

Monolithic metallic copper alloy and NiCrAlY coatings were fabricated by either the cold spray (CS) or the vacuum plasma spray (VPS) deposition processes. Dynamic elastic modulus property measurements were conducted on these monolithic coating specimens between 300 $\mathrm{K}$ and $1273 \mathrm{~K}$ using the impulse excitation technique. The Young's moduli decreased almost linearly with increasing temperature at all temperatures except in the case of the CS Cu-23\% Cr-5\%Al and VPS NiCrAlY, where deviations from linearity were observed above a critical temperature. It was observed that the Young's moduli for VPS $\mathrm{Cu}-8 \% \mathrm{Cr}$ were larger than literature data compiled for $\mathrm{Cu}$. The addition of $1 \% \mathrm{Al}$ to $\mathrm{Cu}-8 \% \mathrm{Cr}$ significantly increased its Young's modulus by 12 to $17 \%$ presumably due to a solid solution effect.

Comparisons of the Young's moduli data between two different measurements on the same $\mathrm{CS} \mathrm{Cu}-23 \% \mathrm{Cr}-5 \% \mathrm{Al}$ specimen revealed that the values measured in the first run were about $10 \%$ higher than those in the second run. It is suggested that this observation is due to annealing of the initial cold work microstructure resulting form the cold spray deposition process.

\section{SUBJECT TERMS}

Young's modulus; Cold sprayed coatings; Vacuum plasma sprayed coatings; NiCrAlY; Copper alloys; Launch vehicles

\begin{tabular}{|c|c|c|c|c|c|}
\hline 16. SECURI & ASSIFICATION & & 17. LIMITATION OF & 18. NUMBER & 19a. NAME OF RESPONSIBLE PERSON \\
\hline $\begin{array}{l}\text { a. REPORT } \\
U\end{array}$ & $\begin{array}{l}\text { b. ABSTRACT } \\
U\end{array}$ & $\begin{array}{l}\text { c. THIS } \\
\text { PAGE } \\
\text { U }\end{array}$ & UU & $\begin{array}{c}\text { PAGES } \\
15\end{array}$ & $\begin{array}{l}\text { 19b. TELEPHONE NUMBER (include area code) } \\
301-621-0390\end{array}$ \\
\hline
\end{tabular}



